\title{
覀性線維性組織球腫の血管造影像
}

\author{
九州大学医学部整形外科 \\ 横山庫一郎・鹿子尘: 健 一 \\ 森人喜八郎・西尾篤人 \\ 福岡中央病院整形外科
}

篠 原典夫・城 戸 正詩

\section{Angiographic Features of Malignant Fibrous Histiocytoma}

by

\author{
K. Yokoyama, K. Kakou, K. Morihisa \& A. Nishio \\ Department of Orthopedic Surgery, Faculty of \\ Medicine, Kyushu Nniversity, Fukuoka \\ N. Shinohara \& M. Kido \\ Department of Orthopedic Surgery, National \\ Fukuoka Central Hospital
}

\begin{abstract}
Arteriography was carried out in 15 cases of malignant fibrous histiocytoma (MFH) to evaluate those as follows; therelationships between angiographic features and histological type, roentogenologic appearance, and prognosis etc.

The investigation proved that histologically myxoid type of MFH was less vascular than other type.

In such a case of MFH that roentogenologically appearing like giant cell tumor, it showed highly vascular pattern.

When a large drainage vein is encased or obstructed at venous phase, the prognosis of the patient is poor.
\end{abstract}

悪性線維組織球腫 (malignant fibrous histiocytoma: MFH) は 1964 年 O’Brien \& Stout が記載 して以来, 報告が相次ぎ, 新しい entity の腫瘍とし て診断，治療の面で研究がすすめられているが，今 回, 九大整形外科及びその関連病院で経験した MFH の症例中, a ngiography を施行した 15 例の造影像に ついて, 特異的所見の有無組織像, 予後との関連等を 検討した.

症例：男性 10 例，女性 5 例，年齢は 20 歳から 77 歳 までで， 8 例は 50 歳以上で高齢者に多く，平均 52.4 歳である.

発生部位は, 軟部では上腕 3 例, 大腿 3 例, 下腿 2 例，骨では，大腿骨 5 例，腸骨 1 例，脛骨 1 例で，下 肢に多く発生している.
方法：手技は主に，大腿動脈または上腕動脈の直接 穿刺により，手動にて $76 \%$ ウログラフインを 30 40 cc 注入し, 連続撮影を行ない, 動脈相, 静脈相を求 めた.

造影所見の分類は所家より多少の相違はあるが，我 々は次の 7 項目に分類し観察した.

(1) Dlsplacement of vessels, (2) Hypervascularity, (3) Tumor stain, (4) A-V shunting (5) Encasement, (7) Irregular margin of a mass (図 1)

結果：腫瘍への blood supply は, 軟部, 骨発生 ともに腫瘍に最も近い主幹動脈より分枝する比較的大 きな動脈より行なわれる.

腫瘍による動脈の圧排像 displacement は 15例中 


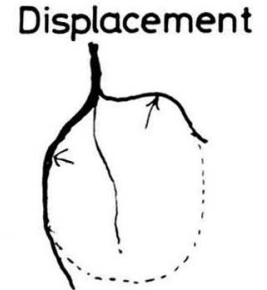

Tumor stain

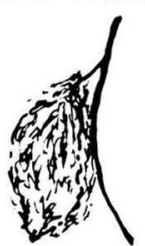

\section{Encasement}

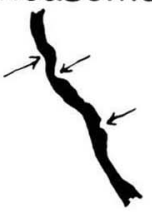

図1造影像のシェーマ
Hypervascularity

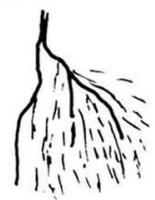

A-V shunting

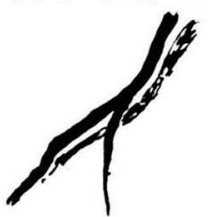

Pooling

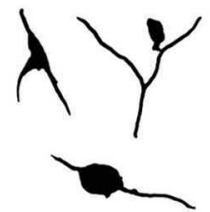

10 例に認めた（表 1 ).

hypervascularity は全例に見られたが，vasculaー rity の程度によって (1) High, (2) Moderate,

(3) Low の 3 段階に分けた.

(1) High：3 例に認め, 動脈初期より明らかな tumor stain に移行し, 濃い amorphous densityを 呈した。.

（2）Moderate：8例に認め, 新生血管による vascular network が比較的明瞭で，血管重複像による reticular pattern を呈した（図2).

(3) Low：4例に見られ, 微細な新生血管によるス リガラス様の淡い density を呈した. このうち 3 例 は, 組織学的に myxoid type であった.

以上 15 例中 12 例は moderate〜low vascularity で, MFH は比較的, 血管新生の少ない腫瘍であると 考えられる.

tumor stain は全例に認めた. これはvascularity の程度に比例する.腫瘍内に血管新生があるととは, 周囲の健常組織と比較すれば明らかで, 腫痬内の新生 血管は正常血管と異なり, 弾性に乏しいため, 静脈相 後期においても, 造影剂の停滞があるために, tumor stain として観察される.

表 1 造影所思出現渪

\begin{tabular}{|lrr|}
\hline Displacement & $10 / 15$ & $66.7 \%$ \\
Hypervascularity & $15 / 15$ & $100 \%$ \\
Tumor stain & $15 / 15$ & $100 \%$ \\
A-V shunt & $5 / 15$ & $33.3 \%$ \\
Encasement & $13 / 15$ & $86.7 \%$ \\
Pooling & $4 / 15$ & $26.7 \%$ \\
Irregularity & $12 / 15$ & $80 \%$ \\
\hline
\end{tabular}

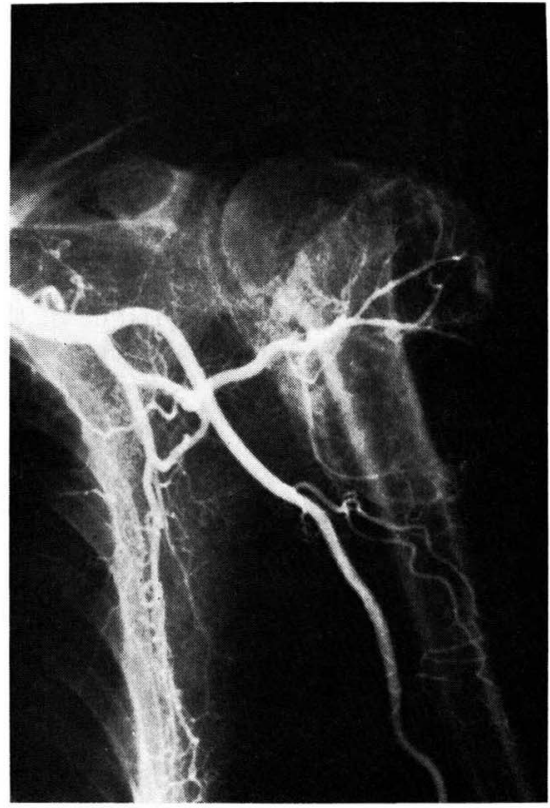

図 2 腫燱に一致して新生血管が認められ 加, 比較的血管は少ない, encasement 热められる

腫瘍内血管の rapid circulation によるといわれ る, A-V shunting は6例に見られ, high vascularity の症例ほど明らかだった。

Encasement は悪性腫瘍には，かなり高頻度にみ られるが，本症でも 13 例に見られ，比較的大きな血 管にも認められた。しかし主幹動脈では，圧排像は認 められても, 虫喰い像はみられなかった，静脈相では drainage vein の encasement を10 例に認めた.

Pooling は 3 例に認めた. これは腫瘍 細胞による 血管控形成によるといわれ，悪性所見とされ，悪性腫 瘍が強く疑われる.

tumor stain によって判る tumor の境界の irrgularity は 12 例に見られた. この所見は悪性を示唆 し，良性腫瘍では，一見被膜を有するように見えるこ 
とが多い.

骨原発の MFH は全例境界不整で, 軟部原発では, 8 例中 4 例は, 比較的境界整であった.

覀性腫瘍の血管造影に高膟に出現する所見は, encasement, neovascularity, irregular margin of a mass 等であるが, 本症もいずれかの所見が認めら れ, 腫瘤の発育速度, 発生部位, 硬さ等の臨床所見を 考え，悪性腫瘍であると判断した。

本症に特異的所見は得られなかったが，vascularityは比較的少なく, 例えば, 高度な hypervascularity を呈す alveolar soft part sarcoma, Grawitz’ tumor の骨転移巣などに比較すると，明らかに less vascular pattern である.

組織学的に myxoid type の MFH は他の組織型 (giant cell type, xanthoma type etc.) に比較 して less vascular pattern であった. これらの予 後は良かった。 因みに, myxoid liposarcoma, extraskeletal myxoid chondrosarcoma 等も豊富な myxomatous matrix を有するが，乙れらも血管に 乏しく，予後の良いことが指摘されている.

巨組胞腫は高度の hypervascularity を呈し A-V shunting, drainage vein の拡張がしばしば見られ る. 本症の中には，単純レ線上，巨組胞腫様に見える ものがあるが, やはり highly vascular pattern で あった.しかし 組織型は giant cell type ではなか った.

次に血管造影像と予後の関連を生存例と死亡例に分 けて検討した.

生存例 8 例中 4 例は, 初回治療より 4 年以上生存 し，血管は少なく，3例は low vascular pattern であった。境界は比較的明瞭で, homogeneous な tumor stain を呈した. drainage vein の encasement は見られず, tumor とは全く隔絶した走 行をしている.

表 2 の case 3 は drainage vein の encasement, pooling がみられ, 術後 1 年 11 力月で肺転移 を来たしている.

case 5 は high vascularity, pooling, drainage vein の encasement 等, すべての所見が陽性で, 予後の悪いことが予想される（表2).

死亡例中, case 5 は low vascular で drainage vein の encasement あなく組織型は myxoid type であった症例で， 3 年 5 力月で死亡しているが，乙れ

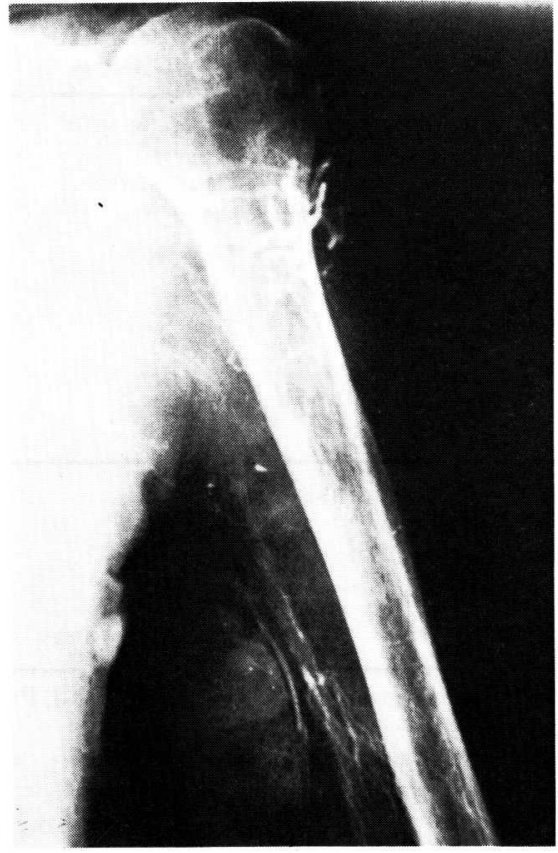

図3写真の如く tumor stain はスリガ ラス様で drainage vein は tumor と隔絶した走行をとっている（術後 3 年 5 力月で死亡した症例)

は治療法に問題があったと考えられる（図 3 )。

他の 5 症例は, 初回治療よりほぼ 2 年以内に死亡し ており，2 例は 1 年以内之いう早い転帰をとってい る. いずれも highly vascular pattern, 大口径の drainage vein の encasement が見られた（表 $3)$.

結語

(1) MFH 15 例の血管造影所見を検討した.

(2) 組織学的に myxoid pattern を呈す MFH は less vascular pattern であった。

(3) X-P で巨組胞腫様のものは highly vascular patternであった.

（4）静脈相で，大口径の drainage vein の encasement，とぎれ像を認めるものは予後が悪い（症 例数が少ないので，更に症例を重ね，検討を続けた (.)

(5) MFH に特界的所見は得られなかった.

（本研究の一部は厚生省がん研究助成金による.） 
表 2 生存者の造影所見分類

4 年以上生存せる者は drainage vein encasement がみられない

\begin{tabular}{|c|c|c|c|c|c|c|}
\hline \multirow{2}{*}{ case } & \multicolumn{3}{|c|}{ Angiographic features and Prognosis } & \multirow{2}{*}{$\begin{array}{l}\text { encasement } \\
\text { of drain. vein }\end{array}$} & \multirow{2}{*}{ pooling } & \multirow{2}{*}{ follow-up } \\
\hline & vascularity & tumor stain & $A-V$ shunt & & & \\
\hline $\begin{array}{l}1 \\
2 \\
3 \\
4 \\
5 \\
6 \\
7 \\
8\end{array}$ & $\begin{array}{l}H \\
H \\
H \\
H \\
H \\
H \\
+ \\
+\end{array}$ & $\begin{array}{l}+ \\
+ \\
+ \\
+ \\
+ \\
+ \\
+ \\
+\end{array}$ & $\begin{array}{l}- \\
- \\
- \\
+ \\
- \\
-\end{array}$ & $\begin{array}{l}+ \\
+ \\
+ \\
+ \\
+ \\
-\end{array}$ & $\begin{array}{l} \pm \\
\pm \\
\pm \\
+ \\
- \\
-\end{array}$ & 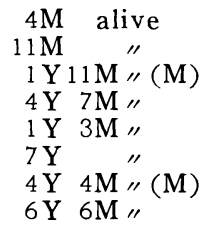 \\
\hline
\end{tabular}

(M) : metastasis

表 3 死亡せる者の造影所見分類

drainage vein の encasement があるものは予後が悪いととがわかる

\begin{tabular}{|c|c|c|c|c|c|c|}
\hline \multirow{2}{*}{ case } & \multicolumn{3}{|c|}{ Angiographic feautures and Prognosis } & \multirow{2}{*}{$\begin{array}{l}\text { encasement } \\
\text { of drain. vein }\end{array}$} & \multirow{2}{*}{ pooling } & \multirow{2}{*}{ follow-up } \\
\hline & vascularity & tumor stain & $A-V$ shunt & & & \\
\hline $\begin{array}{l}1 \\
2 \\
3 \\
4 \\
5 \\
6\end{array}$ & $\begin{array}{l}\text { H } \\
\text { H } \\
\text { H } \\
\text { H } \\
+ \\
+\end{array}$ & $\begin{array}{l}+ \\
+ \\
+ \\
+ \\
+ \\
+\end{array}$ & $\begin{array}{l} \pm \\
\frac{-}{-} \\
\frac{+}{-}\end{array}$ & $\begin{array}{l}+ \\
+ \\
+ \\
+ \\
+\end{array}$ & $\begin{array}{l}\frac{t}{-} \\
+ \\
- \\
-\end{array}$ & 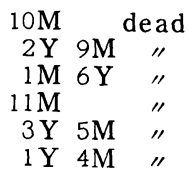 \\
\hline
\end{tabular}

\section{質 問東大整形外科 竹山 信成}

1. 骨の malignant fibrous histiocytoma (MFH) の初回の病理診断は, $\mathrm{MFH}$ と診断された以 外の診断は, どんなものがありましたか.

2. 術前の単純X線と血管撮影から $\mathrm{MFH}$ と部断 が可能ですか.

\section{問 答}

1. Liposarcoma, fibrosarcoma, rhabdomyosarcoma 等が主なものである.

2. MFH に特異的といえるX-線像はないが，とき に巨細胞腫に酷似する像を呈すことがあり，かならず MFH 念頭におくことが必要である. 